\title{
Toxic associations: A review of the predatory behaviors of millipede assassin bugs (Hemiptera: Reduviidae: Ectrichodiinae)
}

\author{
Michael FORTHMAN and Christiane WEIRAUCH \\ Department of Entomology, University of California, 3401 Watkins Drive, Riverside, CA 92521, USA; \\ e-mails:mfort001@ucr.edu; christiane.weirauch@ucr.edu
}

Key words. Ectrichodiinae, millipede, prey specificity, communal predation, Costa Rica, Rhiginia cinctiventris

\begin{abstract}
Ectrichodiinae (Hemiptera: Reduviidae), the millipede assassin bugs, are a speciose group ( $>660$ species) of assassin bugs that appear to be specialist predators on Diplopoda, or millipedes. Apparently capable of coping with the noxious defensive compounds produced by many millipedes, Ectrichodiinae are engaged in a predator-prey relationship with millipedes realized only by few other arthropods. Unfortunately, feeding behaviors of Ectrichodiinae are inadequately documented, rendering this exciting phenomenon largely inaccessible. We here present a literature review on ectrichodiine prey selection and feeding behaviors, with supplemental original observations on Rhiginia cinctiventris (Stål, 1872) in Costa Rica. Thirteen species in 12 genera have been observed to feed on millipedes. The majority of diplopod prey species were reported from the orders Spirostreptida and Spirobolida, whereas Polydesmida are rarely attacked. Ectrichodiinae insert their stylets at the millipede's intersegmental membranes on the ventral and ventro-lateral trunk area or between the head and collum. Communal predation was observed among conspecific nymphs, among groups of nymphs with a conspecific adult, and more rarely among adults. Immature ectrichodiines were rarely observed to engage in solitary predation. Observations on $R$. cinctiventris indicate that this species preys on spirobolid and polydesmid millipedes and are in agreement with behaviors described for other Ectrichodiinae.
\end{abstract}

\section{INTRODUCTION}

Millipedes (Diplopoda) are a diverse group of arthropods that include 16 orders represented by approximately 12,000 species in 145 families (Sierwald \& Bond, 2007). In 11 of these orders, millipedes are protected from predators by chemical defenses produced in glands that vary in number among orders and are located laterally or mid-dorsally in the diplosegments (Eisner et al., 1978; Hopkin \& Read, 1992). The major defense components of these secretions seem to exhibit a phylogenetic pattern: Julida, Spirostreptida, and Spirobolida (Superorder Juliformia) produce benzoquinones; Callipodida and Chordeumatida produce phenols; Glomerida and Polyzoniida produce alkaloids and quinazolinones; Polydesmida produce cyanogenic compounds; and Platydesmida, Siphonocryptida, and Siphonophorida produce terpenoids (Eisner et al., 1978; Hopkin \& Read, 1992; Sierwald \& Bond, 2007). Despite such defenses, many vertebrates prey on millipedes (Sierwald \& Bond, 2007). In addition, some invertebrates are specialized predators or parasitoids on juliform millipedes (Banks, 1911; Picard, 1930; Lawrence, 1984; Eisner et al., 1998; Dejean et al., 2001; Brunke et al., 2009; Larsen et al., 2009). None of these groups of millipede specialists are particularly speciose. This is dramatically different in the Ectrichodiinae, the fifth largest subfamily of Reduviidae (Hemiptera: Heteroptera), or assassin bugs, that appears to be specialized on millipedes (Green, 1925; Haridass \& Ananthakrishnan, 1980; Haridass, 1985).

The circumtropical millipede assassin bugs comprise $>660$ species in 123 genera (Maldonado, 1990; Doug- herty, 1995; Carpintero \& Maldonado, 1996; Weirauch et al., 2009; Chlond, 2010). Species have been collected while feeding on millipedes, but details of the predatorprey relationships, including prey specificity and point of mouthpart insertion are largely undocumented. Thus, it is unknown if Ectrichodiinae target the millipede's nervous system to maximize the impact of their toxic saliva. It is also unknown if Ectrichodiinae target the body regions that possess defensive glands to sequester their own defensive compounds, or if they avoid the millipedes' defense glands. In addition, predation in Ectrichodiinae may be a communal activity (Haridass \& Ananthakrishnan, 1980; Haridass, 1985) rather than a solitary behavior as usually observed in Reduviidae (Readio, 1927; McMahan, 1983; Li et al., 2010), but details on this unusual subsocial behavior are scarce.

Here, we compile published data and evaluate images available on the Internet for prey specificity, point of stylet insertion, and communal predation. In addition, data for Rhiginia cinctiventris (Stål, 1872) are presented based on observations in the field and laboratory at one site in Costa Rica; feeding observations have never been reported for this genus before. Literature and original data were analyzed in response to three questions: (1) Does the literature data suggest a pattern of Ectrichodiinae prey preference for species in particular millipedes orders? (2) Assuming that Ectrichodiinae either target or circumvent the millipede's defense glands, where do they insert their mandibular and maxillary stylets to inject toxic saliva and digestive enzymes? (3) Are communal predation strategies commonly observed in nymphs and adults? 


\section{LITERATURE REVIEW AND ANALYSIS OF ONLINE IMAGE MATERIAL}

Publications and online images containing information on Ectrichodiinae feeding behavior were evaluated for information regarding ectrichodiine and millipede taxa, ectrichodiine developmental stage, stylet insertion, and communal predation (Table 1). Even though some references identified millipedes to genus or species (Cachan, 1952; Miller, 1953; Haridass \& Ananthakrishnan, 1980; Lawrence, 1984; Giliomee, 1985; Ambrose, 1999), the validity of these names have changed over the years and identification without voucher material is tentative. Thus, we focus on establishing a pattern based on the prey order level instead. Victor Cheah (http://www.clubsnap.com/ forums/threads/861603-Assassin-feed-on-millipede; accessed 20 Jun. 2011), Jonker Fourie (http://fireflyafrica. blogspot.com/2009/01/shongololo-millipede.html; accessed 13 Jun. 2011), Helcio Gil-Santana (http://www. nadiplochilo.com/fpseudonannolenidae.html; accessed 18 Aug. 2011), Joce Gordon (http://www. marlothparkhonoraryrangers.co.za/?page_id=976; accessed 18 Oct. 2011), Zichen Wang (http://www.flickr. com/photos/biozcw/5247453267/; accessed 18 Aug. 2011), Eddy Lee (http://www.flickr.com/photos/ lonesomecrow/5750042813/; accessed 18 Aug. 2011), Ted MacRae (http://beetlesinthebush.wordpress.com/ 2009/02/18/millipede-assassin-bug/; accessed 18 Aug. 2011), Alan Weaving (http://imagepro.photography.com/ weaving; accessed 18 Aug. 2011), and Arend van de Wetering (http://www.whatsthatbug.com/2008/08/22/ millipede-assassin-bugs-from-south-africa/; accessed 18 Oct. 2011) took images used in the analysis and gave permission to publish the data and images (Fig. 1). Two images did not specify the photographer or provide contact information; these images were found on the following websites: http://www.flickr.com/photos/ 12639178@N07/5631578778/ (accessed 18 Oct. 2011) and http://www.whatsthatbug.com/2008/08/22/millipedeassassin-bugs-from-south-africa/ (accessed 18 Oct. 2011).

\section{FIELD AND LABORATORY PROCEDURES}

Specimens of Rhiginia cinctiventris were collected at La Selva Biological Research Station, Costa Rica $\left(10.430862^{\circ} \mathrm{N} 84.006467^{\circ} \mathrm{W}\right)$ from August 9-15, 2010. Ectrichodiinae and millipedes were placed individually into petri dishes or larger containers with moist tissue. Immature ectrichodiines were determined to be the same species as adults based on coloration and proximity to adults. Sex and developmental stages were determined prior to feeding observations. Individual specimens or groups of individuals were exposed to millipedes representing the orders Spirobolida and Polydesmida, resulting in 25 trials. For each trial, specimens were removed after $20 \mathrm{~min}$ if the ectrichodiine(s) did not approach, grip, or probe the millipede. If individuals interacted with the millipede, observations continued until the individual(s) had ceased these interactions for more than $15 \mathrm{~min}$ or until after feeding. All ectrichodiine specimens and one representative of each millipede species were preserved in
$100 \%$ ethanol, barcode labeled, databased, and deposited at the Entomological Research Museum at the University of California, Riverside (UCR).

\section{ECTRICHODIINAE PREY SPECIFICITY}

Representatives of 12 Ectrichodiinae genera have been documented in the literature to feed on millipedes in 42 separate observations (Table 1). Seventeen observations involved millipedes in the order Spirostreptida, six in Spirobolida, and one in Polydesmida. Six additional observations included millipedes that could only be identified to the superorder Juliformia, based on identifications made by Rowland Shelley (some online images) and identification keys (Loomis, 1968; Sierwald, http://archive. fieldmuseum.org/millipeet/milli_key.html; accessed 18 Oct. 2011). Two of the 25 laboratory observations and one field observation made by the senior author indicate that Rhiginia cinctiventris preys on Spirobolida and Polydesmida. Although feeding was not observed directly in the field, observation of an adult female and two late instar (3-5) nymphs with swollen abdomens in close proximity to a dead spirobolid millipede (Fig. 2A) indicate a recent meal.

The observation that only three of the 16 millipede orders have been reported as prey of Ectrichodiinae may be, in part, due to a lack of data or may be based on the fact that these orders have high species diversity (Sierwald \& Bond, 2007). However, this observation may also hint to a potential prey preference for the benzoquinoneproducing Juliformia over cyanogenic Polydesmida. The relative toxicity of benzoquinones and cyanogenic compounds to ectrichodiines is unknown. Based on material safety data sheets, benzoquinone has an $\mathrm{LD}_{50}$ of $25 \mathrm{mg} / \mathrm{kg}$ (mouse; oral), whereas hydrogen cyanide has an $\mathrm{LD}_{50}$ of $3.7 \mathrm{mg} / \mathrm{kg}$ (mouse; oral). The degree of toxicity between the two compounds may be relatively similar for ectrichodiines.

\section{POINT OF STYLET INSERTION}

From the literature, only 18 observations made reference to the millipede's body region attacked by ectrichodiines, all of which were on the trunk. Fourteen of these stated that the ventral or ventro-lateral area was targeted (Figs 1C, 1D, 1F, 1J), with 8 of these attacks at intersegmental membranes (Fig. 1I). Four less specific observations by Miller (1953) indicated that ectrichodiines targeted trunk intersegmental membranes, and Lawrence (1984) mentioned intersegmental membranes without reference to body region. Haridass (1985) stated that ectrichodiines also insert stylets at the head-collum intersegmental membrane. In our two laboratory trials, specimens of $R$. cinctiventris inserted stylets at the headcollum intersegmental membrane and/or at intersegmental membranes along the ventral, ventro-lateral, and/or dorsal trunk (Fig. 2B). Overall, the data suggest Ectrichodiinae primarily target the millipede's ventral or ventro-lateral trunk, with some exceptions.

There are several possible explanations for this behavior. These areas may be more penetrable than others, 


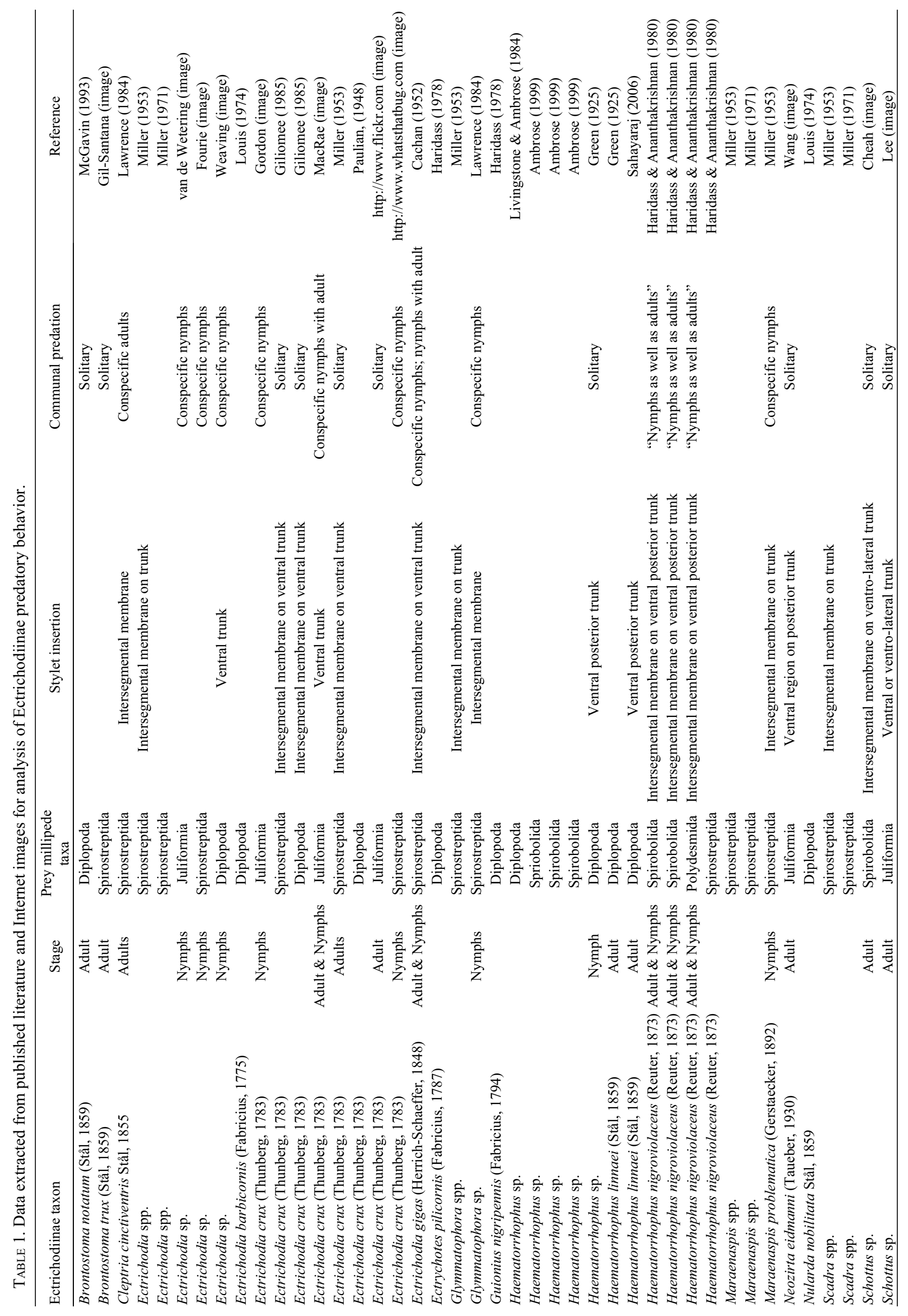



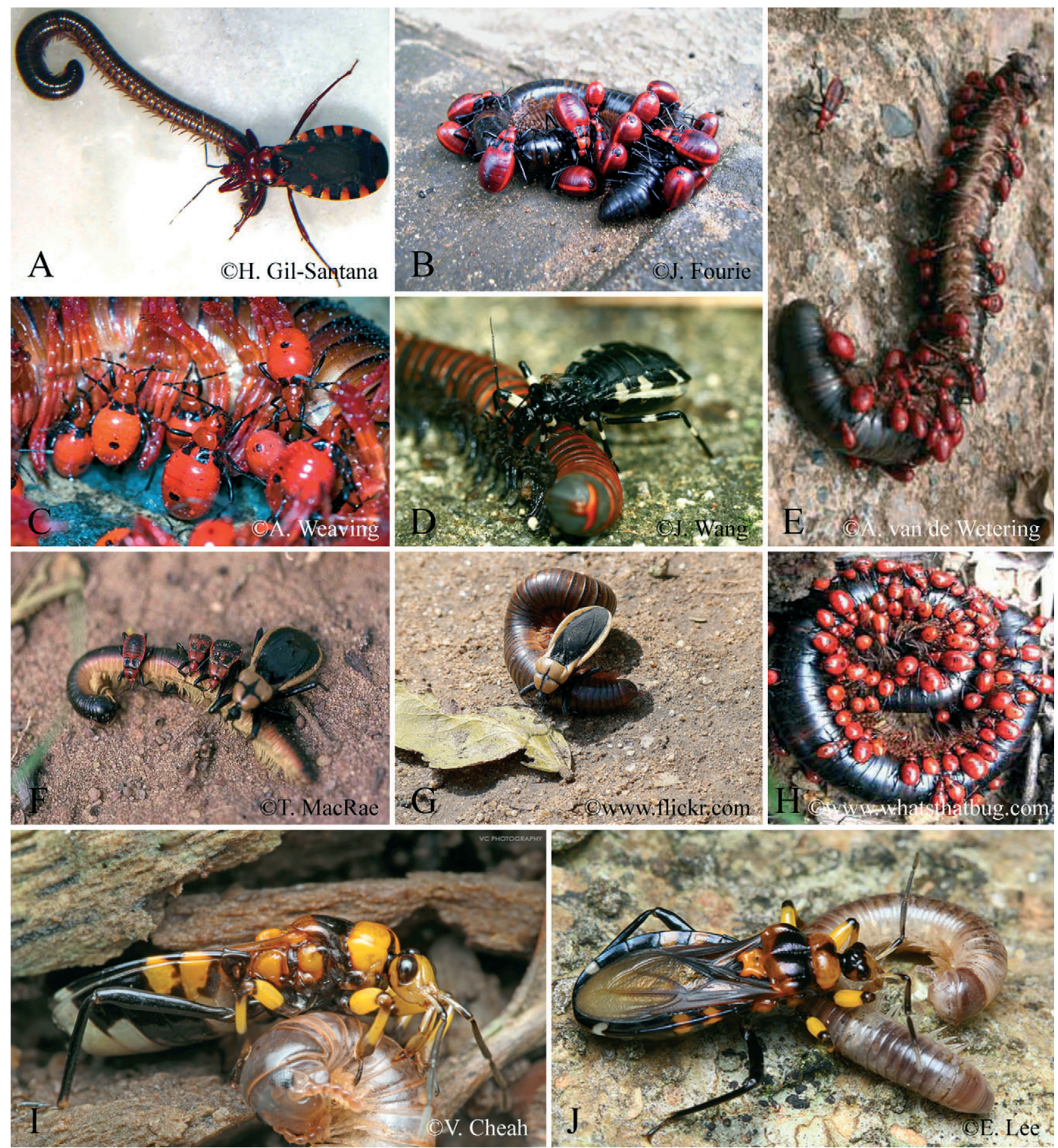

Fig. 1. Internet images used for analysis of Ectrichodiinae predatory behavior. A - An adult Brontostoma trux feeding on a spirostreptid millipede (Gil-Santana). Millipede identified by R. Shelley and ectrichodiine identified by H. Gil-Santana. B - Ectrichodia sp. nymphs communally feed on a spirostreptid millipede (Fourie). C - Ectrichodia sp. nymphs feeding on the venter of a millipede (Weaving). D - An adult Neozirta eidmanni feeding on a juliform millipede carcass (Wang). W. Cai identified the ectrichodiine. E Ectrichodia sp. nymphs communally feed on a juliform millipede (van de Wetering). F - An adult and three immature Ectrichodia crux share a juliform millipede carcass (MacRae). T. MacRae identified the ectrichodiine. G - An adult Ectrichodia crux consumes a juliform millipede (http://www.flickr.com). H - Ectrichodia crux nymphs communally feed on a spirostreptid millipede (http://www.whatsthatbug.com). R. Shelley identified the millipede. I - An adult Schottus sp. feeds on a spirobolid millipede (Cheah). J - An adult Schottus sp. feeds on a juliform millipede (Lee).

making a more suitable entry point for the typically smooth, unarmored stylets (Weirauch, 2003, 2008). Unfortunately, little is known about diplopod cuticular ultrastructure and chemical composition to further sup- port this claim (Subramoniam, 1974; Walker \& Crawford, 1980; Ansenne et al., 1990). Alternatively, Ectrichodiinae may initially target the millipede's ventral ganglia or the supra-oesophageal ganglion to expose the nervous system 
to toxic salivary secretions. The millipede's ventral or head-collum region may be selected to avoid inserting stylets into laterally or dorsally located defensive glands along the trunk during millipede immobilization and consumption. It remains to be shown if, once immobilized, the millipede's defense gland reservoirs are targeted by ectrichodiines to sequester toxic secondary metabolites. At least half of the genera of Ectrichodiinae exhibit aposematic coloration to a larger extent than seen in most other reduviid subfamilies. Although ectrichodiines are presumably well protected from vertebrate predation due to their generally powerful bites and defensive secretions (Louis, 1974; Ambrose, 1999), a millipede diet may provide ectrichodiines with additional defensive benefits in the form of toxic secondary metabolites. Secondary defense metabolites have been investigated in other insects, such as aposematically colored Lepidoptera that sequester many chemicals from their host plants and biochemically alter them for defense purposes (Bowers, 1990; Nishida, 2002). Ectrichodiinae may potentially employ a similar strategy by targeting the defense gland reservoirs.

\section{COMMUNAL PREDATORY STRATEGIES}

Evidence for communal predation comprises 13 observations. Of these, two involved groups of conspecific nymphs in the presence of a conspecific adult, whereas eight involved groups of conspecific nymphs. Conspecific adults engaging in communal behaviors have only been documented in Cleptria cinctiventris Stål (1855) [Lawrence, 1984]. Evidence of immatures engaging in solitary predation has only been documented for a Haematorrhophus species (Green, 1925). Communal predation was observed in only one of our laboratory trials with $R$. cinctiventris (Fig. 2C): early instar (1-2) nymphs, in the presence of an adult female and two later instar nymphs, frequently attempted predation on a millipede without immobilizing it. Overall, the data may indicate that communal, conspecific feeding among immatures or immatures and adults is the rule but rather an exception among adults. One potential explanation is that the salivary secretions produced by a single nymph may not be sufficiently toxic to immobilize and kill a millipede. Thus, the attack of multiple individuals may be necessary to increase the toxic effects, especially to subdue large-bodied prey items.

\section{CONCLUSION}

The predator-prey association between Ectrichodiinae and millipedes was first documented almost a century ago (Green, 1925), but has since received little attention. Judging from published data, it is obvious that the feeding behavior of Ectrichodiinae is still poorly understood. About $2 \%$ of ectrichodiine species have been documented to prey on millipedes, leaving ample room to further test the claim that Ectrichodiinae, as a group, specialize on millipedes. Based on our analysis, Ectrichodiinae may be exclusive millipede specialists, with a potential preference for the benzoquinone-producing Juliformia. Milli-
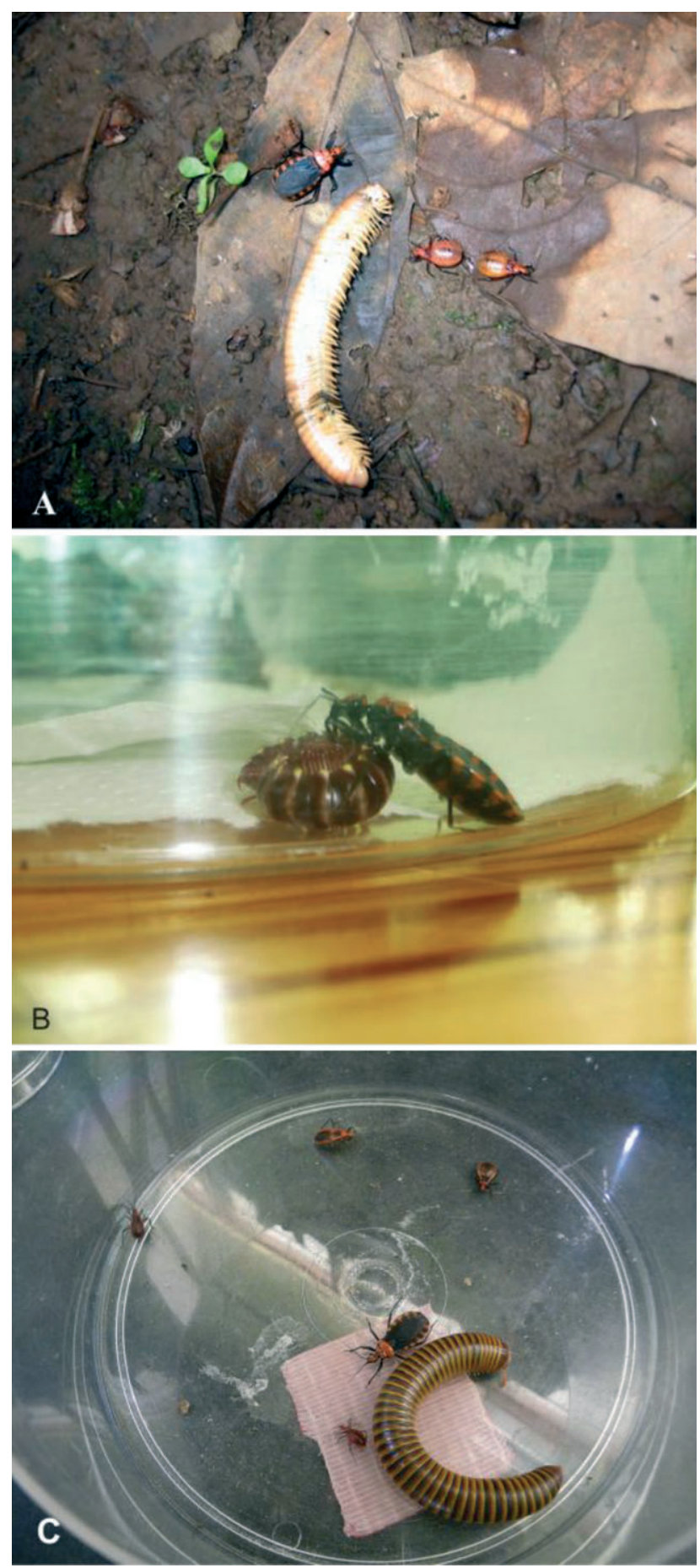

Fig. 2. Field and laboratory images of Rhiginia cinctiventris predation on millipedes at La Selva Biological Station, Costa Rica. A - Field image of an adult and two immature Rhiginia cinctiventris near a spirobolid millipede carcass at La Selva Biological Station, Costa Rica. B - An adult female feeds on a small polydesmid millipede. C - An adult female, two early instar nymphs, and two later instar nymphs in the presence of a spirobolid millipede.

pedes were usually not identified below the order level in the literature and online images. Thus, future investigations should attempt accurate genus or species determination of millipedes. Furthermore, the millipede's ventral trunk area and intersegmental membranes, including 
between the head and collum, are typically targeted. Whether these areas are attacked in relation to the location of the millipede nervous system or defense glands remains to be investigated. Lastly, immature and adult Ectrichodiinae exhibit both solitary and communal predation. The majority of observations suggest that immatures typically exhibit communal predation, whereas adults usually predate solitarily. Given that these conclusions are general and preliminary, it is imperative that future studies provide detailed documentation regarding these aspects of ectrichodiine predation. Other relevant investigations that will contribute to understanding this phenomenon include examining the chemical composition of ectrichodiine salivary secretions and the ability of ectrichodiines to sequester secondary metabolites from diplopods for defense.

ACKNOWLEDGEMENTS. We would like to thank the students and instructors of the two-week Organization for Tropical Studies field-course in Costa Rica (August 2010) for their assistance in acquiring specimens of Rhiginia cinctiventris and millipedes. We further extend our appreciation to P. Sierwald of the Field Museum, Chicago, Illinois, for her assistance in providing references for millipede taxonomy and to W. Cai of the China Agricultural University for verifying the identifications of some Asian Ectrichodiinae. Lastly, the senior author would like to thank his great-uncle T. Bruce for the financial assistance that permitted his trip to Costa Rica, giving the author the opportunity to investigate this intriguing phenomenon. Funding was also provided by the National Science Foundation PEET Grant DEB 093333853 to CW and UCR Graduate Division to MF.

\section{REFERENCES}

Ambrose D.P. 1999: Assassin Bugs. Science Publishers, Enfield, $\mathrm{NH}, 337 \mathrm{pp}$.

Ansenne A., Compère P. \& Goffinet G. 1990: Ultrastructural organization and chemical composition of the mineralized cuticle of Glomeris marginata (Myriapoda, Diplopoda). In Minelli A. (ed.): Proceedings of the 7th International Congress of Myriapodology. Brill, Leiden, pp. 125-134.

Banks N. 1911: A curious habit of one of our phorid flies. Proc. Entomol. Soc. Wash. 13: 212-214.

Bowers M.D. 1990: Recycling plant natural products for insect defense. In Evans D.L. \& Schmidt J.O. (eds): Insect Defenses: Adaptive Mechanisms and Strategies of Prey and Predators. SUNY Press, Albany, NY, pp. 353-386.

Brunke A.J., Bahlai C.A., Sears M.K. \& Hallett R.H. 2009: Generalist predators (Coleoptera: Carabidae, Staphylinidae) associated with millipede populations in sweet potato and carrot fields and implications for millipede management. Environ. Entomol. 38: 1106-1116.

Cachan P. 1952: Etude de la prédation chez les Réduvides de la région Éthiopienne. 1. La prédation en groupe chez Ectrichodia gigas H-Sch. Phys. Comp. Oecol. 2: 378-385.

Carpintero D.J. \& Maldonado J. 1996: Diagnostic characters and key to the genera of American Ectrichodiinae (Heteroptera, Reduviidae). Caribb. J. Sci. 32: 125-141.

Chlond D. 2010: A new, remarkable genus and two new species of Ectrichodiinae (Hemiptera: Heteroptera: Reduviidae) from Madagascar. Zootaxa 2522: 61-68.

Dejean A., Suzzoni J.P. \& Schatz B. 2001: Behavioral adaptations of an African ponerine ant in the capture of millipedes. Behaviour 138: 981-996.
DougherTy V. 1995: A review of the New World Ectrichodiinae genera (Hemiptera: Reduviidae). Trans. Am. Entomol. Soc. 121: 173-225.

Eisner T., Alsop D., Hicks K. \& Meinwald J. 1978: Defensive secretions of millipeds. In Bettini S. (ed.): Arthropod Venoms. Springer, Berlin, pp. 41-72.

Eisner T., Eisner M., Attygalle A.B., Deyrup M. \& Meinwald J. 1998: Rendering the inedible edible: circumvention of a millipede's chemical defense by a predaceous beetle larva (Phengodidae). Proc. Natl. Acad. Sci. USA 95: 1108-1113.

Giliomee J.H. 1985: A millipede assassinated. Afr. Wildlife 39: 149.

Green W.E. 1925: The President's address. Proc. Entomol. Soc. Lond. 1924: clxi-ccii.

HARIDASS E.T. 1978: Biological and Ethological Studies on some South Indian Reduviids (Hemiptera - Reduviidae). Ph.D. Thesis, University of Madras, Madras.

HARIDASS E.T. 1985: Feeding and ovipositional behavior in some reduviids (Insecta - Heteroptera). Proc. Indian $A S-$ Anim. Sci. 94: 239-247.

HaRidass E.T. \& ANANTHAKRISHNAN T.N. 1980: Models for the predatory behavior of some reduviids from southern India (Insecta - Heteroptera - Reduviidae). Proc. Indian AS Anim. Sci. 89: 387-402.

HopkIN S.P. \& READ H.J. 1992: The Biology of Millipedes. Oxford University Press, Oxford, UK, 233 pp.

Larsen T.H., Lopera A., Forsyth A. \& Génier F. 2009: From coprophagy to predation: a dung beetle that kills millipedes. Biol. Letters 5: 152-155.

LaWrenCE R.F. 1984: The Centipedes and Millipedes of Southern Africa: a Guide. A.A. Balkema, Cape Town, 148 pp.

Li H., Zhao G.Y., Cao L.M., Xu K. \& Cai W.Z. 2010: Taxonomic and bionomic notes on the white spot assassin bug Platymeris biguttatus (Linnaeus) (Hemiptera: Reduviidae: Reduviinae). Zootaxa 2644: 47-56.

Livingstone D. \& AmBrose D.P. 1984: Adaptive modifications of the Reduviidae of the scrub jungles and semi-arid zones of the Palghat Gap, India - an evolutionary approach. J. Bombay Nat. Hist. Soc. 81: 583-595.

Loomis H.F. 1968: A checklist of the millipedes of Mexico and Central America. U.S. Natn. Mus. Bull. 266: 1-137.

LouIs D. 1974: Biology of Reduviidae of cocoa farms in Ghana. Am. Midl. Nat. 91: 68-89.

Maldonado J. 1990: Systematic catalogue of the Reduviidae of the world (Insecta: Heteroptera). Caribb. J. Sci. Special Edition: $1-694$.

McGavin G.C. 1993: Bugs of the World. Facts on File, New York, NY, 192 pp.

McMahan E.A. 1983: Adaptations, feeding preferences, and biometrics of a termite-baiting assassin bug (Hemiptera: Reduviidae). Ann. Entomol. Soc. Am. 76: 483-486.

MilLER N.C.E. 1953: Notes on the biology of the Reduviidae of southern Rhodesia. Trans. Zool. Soc. London 27: 541-672.

Miller N.C.E. 1971: The Biology of the Heteroptera. E.W. Classey, Hampton, 206 pp.

Nishida R. 2002: Sequestration of defensive substances from plants by Lepidoptera. Annu. Rev. Entomol. 47: 57-92.

Paulian R. 1948: Sur quelques insectes guanobies de la Coted'Ivoire. Publ. Mus. Hist. Nat. Paris 10: 63-68.

PicARD F. 1930: Sur le parasitisme d'un Phoride (Megaselia cuspidata Schmitz) aux dépens d'un Myriapode. Séance du 25 Février 1930: 180-183.

REadio P.A. 1927: Studies on the biology of the Reduviidae of America north of Mexico. Kansas Univ. Sci. Bull. 17: 1-291. 
SAHAYARAJ K. 2006: Ecological adaptive features of hunter reduviids (Insecta: Heteroptera: Reduviidae Latreille 1807) and their biological control potential. In Gupta V.K. \& Verma A.K. (eds): Perspectives in Animal Ecology and Reproduction. Vol. 3. Daya Publishing House, Delhi, pp. 22-48.

SieRWALD P. \& Bond J.E. 2007: Current status of the myriapod class Diplopoda (millipedes): taxonomic diversity and phylogeny. Annu. Rev. Entomol. 52: 401-420.

Subramoniam T. 1974: Histochemical study on cuticle of a millipede Spirostreptus asthenes (Diplopoda: Myriapoda). Acta Histochem. 51: 200-204.

WALKER L.J. \& CRAWFORD C.S. 1980: Integumental ultrastructure of the desert millipede, Orthoporus ornatus (Girard)
(Diplopoda: Spirostreptidae). Int. J. Insect Morphol. 9: 231-249.

Weirauch C. 2003: Ein Beitrag zum phylogenetischen System der Reduviidae (Heteroptera). Dissertation. Fachbereich Biologie/Chemie/Pharmazie. Freie Universitat Berlin, 279 pp. WeIrauch C. 2008: Cladistic analysis of Reduviidae (Heteroptera: Cimicomorpha) based on morphological characters. Syst. Entomol. 33: 229-274.

Weirauch C., Rabitsch W. \& Redei D. 2009: Austrokatanga, gen. nov., new genus of Ectrichodiinae (Hemiptera: Heteroptera: Reduviidae) from Australia. Zootaxa 2094: 1-15.

Received October 24, 2011; revised and accepted January 13, 2012 